\title{
PERIKANAN PANCING TONDA DI PERAIRAN PELABUHAN RATU*)
}

\author{
Enjah Rahmat' ${ }^{1)}$ dan Asri Patadjangi1) \\ 1) Teknisi Litkayasa pada Balai Riset Perikanan Laut, Muara Baru-Jakarta \\ Teregristasi I tanggal: 23 Juli 2008; Diterima setelah perbaikan tanggal: 24 Juli 2008; Disetujui terbit tanggal: 17 September 2008
}

\section{PENDAHULUAN}

Pancing tonda yaitu pancing yang pada umumnya tanpa pemberat dan dipasang di sekitar permukaan air dan ditarik oleh kapal (Pusat Informasi Pelabuhan Perikanan, 2007). Pancing tonda menggunakan ikan umpan segar atau umpan tiruan. Pancing tonda dikenal juga dengan nama pancing tarik, ada juga beberapa nama daerah untuk pancing tonda seperti pancing irid atau klewer (Jawa), pancing kaladalam atau kabalancam (Madura), pancing pengenser (Bawean), pancing pengambes (Jawa Timur), pancing kakahu (Ambon), dan lain-lain (Subani \& Barus, 1989).

Sejak tahun 2004 alat tangkap pancing tonda dengan alat bantu rumpon laut dalam mulai beroperasi di perairan sebelah Selatan Palabuhan Ratu. Alat ini merupakan salah satu upaya nelayan untuk mencari jenis alat penangkap ikan yang nilai produktivitas cukup baik. Di samping itu, dapat memberikan jawaban atas penurunan hasil tangkapan akibat biaya operasional yang kurang proporsional pada nilai produksi hasil tangkapan (Pelabuhan Perikanan Nusantara Pelabuhan Ratu, 2007).

Tujuan penulisan ini adalah hendak menguraikan perkembangan perikanan pancing tonda di perairan Pelabuhan Ratu dan hubungan dengan ada sejumlah rumpon yang telah dipasang di selatan Pelabuhan Ratu.

\section{POKOK BAHASAN}

\section{Bahan dan Tata Cara}

Penelitian dilaksanakan pada bulan Maret 2008 di Pelabuhan Perikanan Nusantara Pelabuhan Ratu. Penelitian dilakukan dengan cara wawancara dan pengamatan langsung di lapangan. Data aspek-aspek perikanan seperti karakteristik armada (dimensi kapal, mesin, alat tangkap, alat bantu penangkapan, komposisi hasil tangkapan, dan lain-lain) didapat dari Pelabuhan Perikanan Nusantara Pelabuhan Ratu dan Dinas Perikanan dan Kelautan Dati II Sukabumi, sedangkan data dan informasi daerah penangkapan, dan teknik pengoperasian alat tangkap didapat dari hasil wawancara dengan nelayan.

\section{PERKEMBANGAN PERIKANAN PANCING TONDA}

Alat tangkap pancing tonda di Pelabuhan Ratu dikenal sebagai pancing rumpon dan pancing tuna. Disebut sebagai pancing rumpon karena daerah penangkapan pada umumnya di sekitar rumpon, sedangkan dikenal sabagai pancing tuna karena jenisjenis ikan tuna merupakan sasaran spesies penangkapan.

Sebelum ada rumpon sistem penangkapan ikan cakalang (Katsuwonus pelamis) dan tuna (Thunnus) dilakukan dengan cara mencari atau mengejar gerombolan ikan. Dengan cara ini waktu penangkapan kurang efektif karena daerah penangkapan tidak jelas atau berpindah-pindah mengikuti ruaya ikan dan biaya operasional terutama biaya untuk bahan bakar untuk mencari gerombolan ikan cukup tinggi.

Perikanan pancing tonda di Pelabuhan Ratu mulai berkembang setelah ada rumpon laut dalam yang dipasang di perairan sebelah selatan Pelabuhan Ratu pada posisi antara $105^{\circ} 30^{\prime}-106^{\circ} 50^{\prime}$ BT dan 6 $6^{\circ} 59^{\prime}-8^{\circ} 22^{\prime}$ LS (Gambar 1). Pemasangan rumpon di perairan tersebut dimulai pada tahun 20042 unit. Model rumpon yang digunakan adalah model rumpon yang telah diterapkan oleh Yayasan Anak Nelayan Indonesia. Rumpon tersebut didatangkan dari Sulawesi Selatan. Uji coba penangkapan ikan dengan alat tangkap pancing tonda di sekitar rumpon dilakukan oleh nelayan yang berasal dari Sindang Biru (Jawa Timur). Selanjutnya, sampai dengan tahun 2007 tercatat ada 24 rumpon yang sudah dipasang di perairan selatan Pelabuhan Ratu dari 60 rumpon yang telah dipasang di perairan Jawa Barat (Pelabuhan Perikanan Nusantara Pelabuhan Ratu, 2007). Menurut Pelabuhan Perikanan Nusantara Pelabuhan Ratu (2007) hasil uji coba menunjukkan bahwa alat bantu rumpon dapat:

1. Mengurangi waktu tempuh ke daerah penangkapan (waktu operasi penangkapan lebih efektif).

2. Mengurangi biaya operasional 50 sampai dengan $60 \%$ (biaya operasional lebih efisien).

3. Meningkatkan laju penangkapan.

Berkembangnya alat tangkap pancing tonda, karena dilibatkan nelayan non rumponisasi untuk bergabung memanfaatkan rumpon. Dengan cara demikian, pemasangan dan pemanfaatan rumpon sebagai alat bantu penangkapan ikan yang pada awalnya memicu konflik antar nelayan dapat diatasi dengan cara musyawarah. Dalam hal ini Pelabuhan Perikanan Nusantara Pelabuhan Ratu sangat berperan.

\section{PERKEMBANGAN ARMADA}

Jumlah unit kapal pancing tonda yang beroperasi 
dan menggunakan Pelabuhan Perikanan Nusantara Pelabuhan Ratu sebagai fishing base sampai dengan tahun 2007 tercatat 29 unit kapal. Kapal pancing tonda tersebut pada umumnya merupakan kapal kayu dengan ukuran (LxBxD) 12,30x2,90x1,00 m, bobot kapal di bawah 10 GT dan menggunakan 2 mesin dengan kekuatan 22 sampai dengan 30 PK/HP. Merek mesin yang digunakan bervariasi antara lain Fanter, Mitsubishi, Yanmar, MWM, atau Jiandong. Jumlah anak buah kapal rata-rata 5 orang (Raphita et al., 2007).

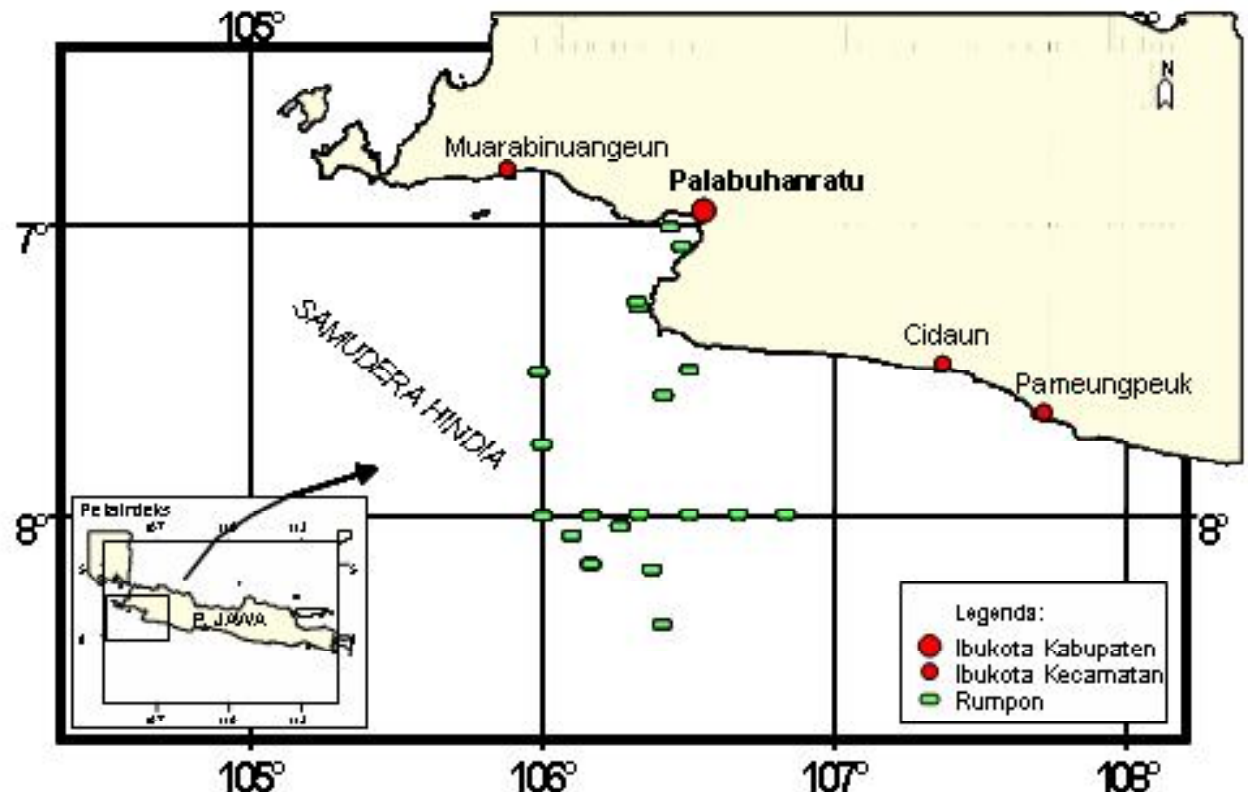

Gambar 1. Daerah penangkapan (rumpon) pancing tonda nelayan Pelabuhan Ratu, bulan Maret 2007.

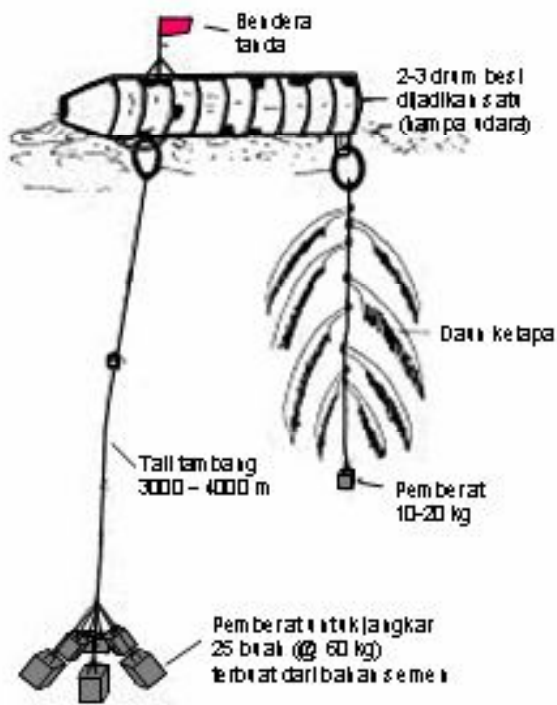

Gambar 2. Jenis rumpon laut dalam.

Jumlah kapal yang beroperasi mengalami kenaikan dari 8 kapal per bulan pada tahun 2005 menjadi 15 kapal per bulan pada tahun 2007 (naik 88\%), begitupun juga dengan jumlah trip penangkapan mengalami kenaikan $41 \%$ yaitu dari 17 trip per bulan menjadi 24 trip per bulan. Kenaikan jumlah trip penangkapan dan jumlah kapal yang beroperasi seiring dengan meningkat jumlah rumpon yang dipasang di selatan Pelabuhan Ratu yaitu dari 4 unit pada tahun 2005 menjadi 24 unit rumpon pada tahun 2007. Pada
Gambar 4. dapat dilihat rata-rata jumlah trip bulanan dan jumlah kapal pancing tonda yang beroperasi di perairan Pelabuhan Ratu.

Pada bulan Maret 2008 jumlah unit pancing tonda bertambah 9 unit kapal bantuan dari pemerintah untuk kelompok nelayan di Pelabuhan Ratu. Spesifikasi kapal pancing tonda dibuat sama dengan kapal pancing tonda nelayan Pelabuhan Ratu, perbedaan terletak pada material kapal yang seluruhnya terbuat 
dari bahan baku fiberglass. Kapal bantuan ini mempunyai ukuran LxBxD adalah 12,5x2,6x1,4 m, dengan ruang muat ikan per palka ikan $10,5 \mathrm{~m}^{3}$. Mesin penggerak menggunakan mesin diesel 45 sampai dengan $70 \mathrm{BHP}$, dengan kecepatan kapal pada kondisi penuh 7 sampai dengan 10 knot. Daya muat tangki bahan bakar $600 \mathrm{I}$, tangki air tawar $400 \mathrm{I}$, dan jumlah anak buah kapal dapat mencapai 8 orang.
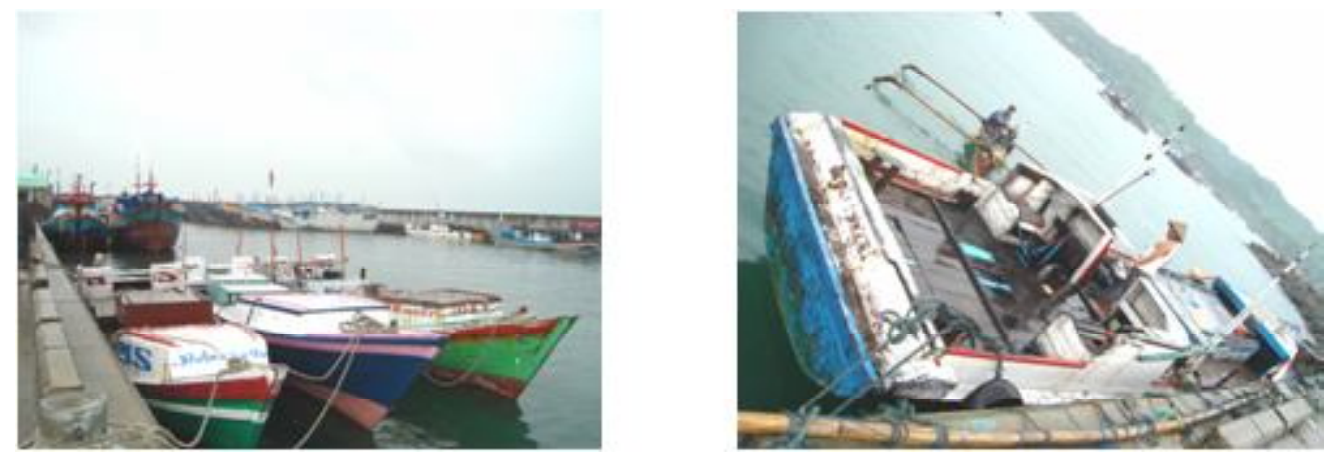

Gambar 3. Armada kapal motor pancing tonda.

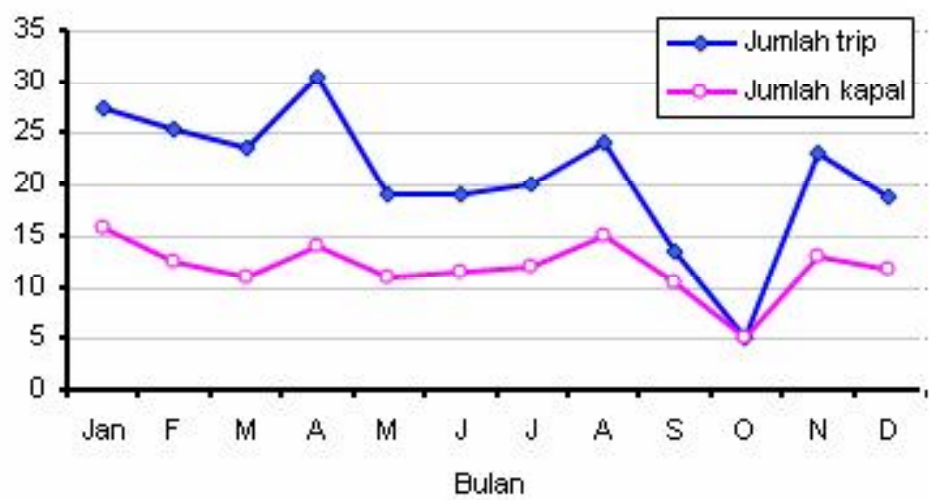

Gambar 4. Rata-rata jumlah trip bulanan dan jumlah kapal pancing tonda yang beroperasi di Pelabuhan Ratu, tahun 2005 sampai dengan 2007.

\section{PENGOPERASIAN ALAT TANGKAP}

Kapal pancing tonda nelayan Pelabuhan Ratu pada umumnya diawaki oleh 5 orang anak buah kapal terdiri dari 1 orang nakhoda atau juru mudi yang merangkap fishing master, 1 orang juru mesin merangkap pemancing dan 3 orang pemancing.

Operasi penangkapan dimulai dengan menentukan daerah atau lokasi pemancingan (fishing ground) yaitu di sekitar rumpon, karena jenis-jenis ikan baik yang berukuran kecil maupun besar pada saat-saat tertentu berkumpul di sekitar rumpon untuk berlindung dan mencari makan. Dengan ada rumponrumpon tersebut, maka operasional pancing tonda dapat dilakukan sepanjang tahun dan tidak tergantung musim penangkapan. Nelayan sudah mengetahui posisi rumpon-rumpon tersebut. Dengan menggunakan alat bantu penentu posisi (GPS) rumpon-rumpon yang akan dituju sudah diketahui letak dengan demikian, jarak dan waktu tempuh ke rumpon sudah dapat diperkirakan. Dalam 1 trip penangkapan dapat dilakukan pada 5 rumpon dan berlangsung selama rata-rata 2 sampai dengan 3 hari. Rumpon terdekat yang dijadikan sebagai daerah penangkapan armada pancing tonda dapat ditempuh dalam waktu 14 jam dari Pantai Pelabuhan Ratu dengan kecepatan kapal 8 mil per jam. Pada malam hari kapal-kapal pancing tonda bermalam di laut dengan cara mengikatkan kapal ke rumpon. Setiap unit rumpon hanya dapat menampung 5 unit kapal pancing tonda, bila lebih maka tali rumpon akan putus karena tidak kuat menahan beban kapal yang diikat dirumpon.

Pancing tonda dioperasikan di siang hari sesuai dengan kebiasaan makan ikan cakalang (Katsuwonus pelamis) dan tuna (Thunnus). Operasi penangkapan pagi hari mulai pukul 05.00 sampai dengan 10.00 dan sore hari pukul 13.00 sampai dengan 17.00 .

Pancing tonda dipasang di bagian buritan kapal yaitu 1 unit diikat di sisi sebelah kiri, 1 unit di sebelah kanan dan 3 unit di bagian belakang, kemudian pancing dilepas dan diulur sampai dengan jarak 5 sampai dengan $12 \mathrm{~m}$ (Gambar 5). Mata pancing yang digunakan nomor 7 dan 8, mata pancing tersebut buatan lokal dan tidak bermerek. Mata pancing dilengkapi dengan umpan tiruan yang terbuat dari 
bahan kayu, plastik bekas compact disk atau bahan karet dengan variasi benang berwarna-warni yang dibentuk menyerupai ikan terbang, cumi-cumi (Loligo sp.), layang (Decapterus sp.). dan lain-lain.

Alat tangkap pancing tonda adalah jenis alat tangkap aktif. Dalam pengoperasian alat tangkap ini ditarik oleh kapal secara horisontal pada permukaan air dengan kecepatan kapal 8 sampai dengan 9 mil per jam. Mata pancing yang dilengkapi dengan umpan tiruan akan timbul tenggelam di permukaan laut. Gerakkan ikan umpan tiruan yang aktraktif ini akan mengundang ikan sasaran untuk memangsa. Sasaran penangkapan adalah ikan cakalang (Katsuwonus pelamis) dan jenis-jenis tuna (Thunnus). Sedangkan jenis-jenis ikan hasil tangkapan sampingan (bycatch) adalah jenis ikan lemadang (Coryphaena hippurus), dan jenis-jenis tongkol (Euthynnus affinis).

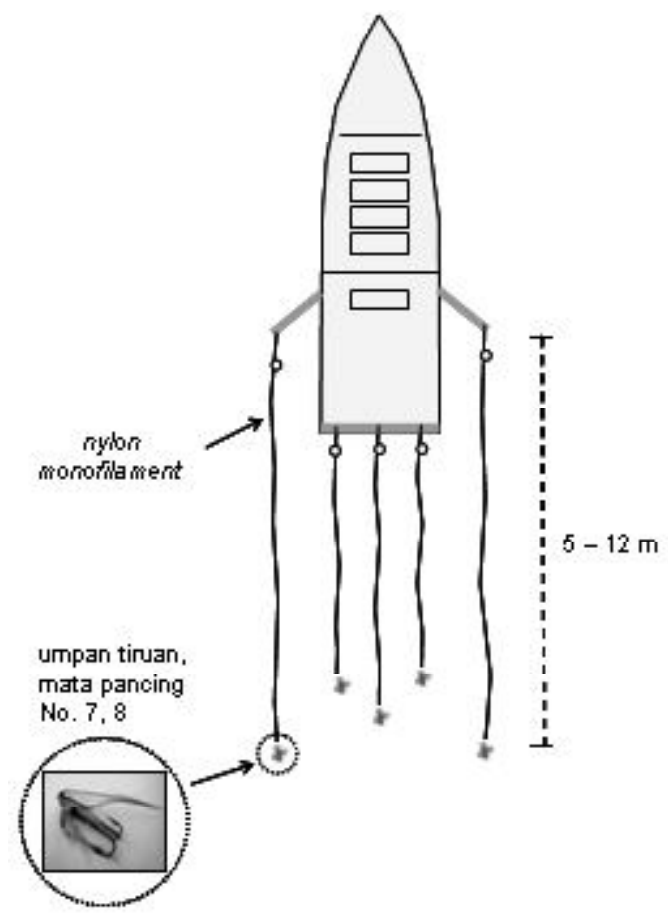

Gambar 5. Skema pemasangan pancing pada kapal pancing tonda.

Selain pancing tonda, dibawa juga alat tangkap lain sebagai alat tangkap tambahan. Alat tangkap tambahan digunakan apabila alat tangkap pancing tonda yang dioperasikan tidak mendapatkan hasil seperti yang diharapkan. Adapun ikan sasaran untuk alat tangkap tambahan ini sama dengan pancing tonda yaitu jenis-jenis tuna (Thunnus) dan cakalang (Katsuwonus pelamis).

Pada umumnya alat tangkap tambahan yang digunakan adalah alat tangkap pancing ulur, ada juga yang menggunakan jaring insang hanyut (drift gillnet) tetapi yang menggunakan drift gillnet sebagai alat tangkap tambahan baru 2 unit kapal tonda.

Alat tangkap pancing ulur sebagai alat tangkap tambahan terdiri atas 3 jenis, yaitu:

1. Pancing ulur dengan kedalaman pemancingan antara 40 sampai dengan $60 \mathrm{~m}$. Pancing ulur ini dikalangan nelayan dikenal dengan nama coping.

2. Pancing ulur yang dioperasikan di permukaan laut. Pancing ulur ini menggunakan layang-layang pada saat pengoperasian, untuk mempertahankan posisi pancing berada di permukaan laut.

3. Pancing ulur dengan kedalaman pemancingan 15 $\mathrm{m}$. Pancing ulur ini dikalangan nelayan dikenal dengan nama caber.

\section{HASIL TANGKAPAN}

Produksi ikan hasil tangkapan pancing tonda di Pelabuhan Ratu periode tahun 2005 sampai dengan 2007 terdiri atas ikan cakalang (Katsuwonus pelamis) dengan rata-rata produksi 12,4 ton per bulan, tuna sirip kuning atau madidihang (Thunnus albacares) rata-rata 7,7 ton per bulan dan tuna mata besar (Thunnus obesus) rata-rata produksi mencapai 1,8 ton per bulan. Produksi ikan cakalang (Katsuwonus pelamis) tertinggi pada bulan April tahun 2006 (43,8 ton), tuna sirip kuning tertinggi pada bulan Januari 2006 (21,2 ton) dan tuna mata besar (12,9 ton) tertangkap pada April 2007. Pada Gambar 6, disajikan rata-rata produksi per bulan ikan sasaran penangkapan alat tangkap pancing tonda di perairan Pelabuhan Ratu periode tahun 2005 sampai dengan 2007. 
Tabel 1. Jenis-jenis ikan hasil tangkapan pancing tonda di Pelabuhan Ratu, periode tahun 2005 sampai dengan 2007

\begin{tabular}{|c|c|c|c|c|}
\hline \multirow{2}{*}{ No. } & \multirow{2}{*}{ Spesies } & \multicolumn{3}{|c|}{ Produksi (kg) } \\
\hline & & 2005 & 2006 & 2007 \\
\hline \multicolumn{5}{|c|}{ Target penangkapan: } \\
\hline 1. & Katsuwonus pelamis & 87.975 & 200.410 & 132.534 \\
\hline 2. & Thunnus albacares & 74.127 & 97.452 & 89.782 \\
\hline & Thunnus obesus & - & 7.399 & 53.188 \\
\hline & Total & 164.107 & 307.267 & 277.511 \\
\hline \multicolumn{5}{|c|}{ Hasil sampingan: } \\
\hline 1. & Thunnus tonggol & - & 72 & 136 \\
\hline 2. & Auxis thazard & 102 & 328 & 449 \\
\hline 3. & Auxis rochei & - & - & 81 \\
\hline 4. & Cacrcharinidae & 29 & - & 24 \\
\hline 5. & Alopias pelagicus & - & - & 17 \\
\hline 6. & Alopias superciliosus & - & - & 58 \\
\hline 7. & Makaira indica & 92 & 743 & 1151 \\
\hline 8. & Istiophorus platypterus & - & 33 & 189 \\
\hline 9. & Xiphias gladius & - & 131 & 124 \\
\hline 10. & Decapterus spp. & - & - & 935 \\
\hline 11. & Coryphaena hippurus & 61 & 2761 & 5250 \\
\hline 12. & Lain-lain & 41 & - & 150 \\
\hline \multicolumn{2}{|r|}{ Total } & 2.330 & 6.074 & 10.571 \\
\hline
\end{tabular}

Sumber: Pelabuhan Perikanan Nusantara Pelabuhan Ratu (2008)

Pada Gambar 7 disajikan rata-rata produksi jenis ikan hasil tangkapan sampingan (bycatch) periode tahun 2005 sampai dengan 2007. Jenis ikan yang termasuk hasil tangkapan sampingan didominasi oleh jenis ikan lemadang (Coryphaena hippurus), layang (Decapterus spp.), jangilus (Makaira indica), dan tongkol banjar (Auxis thazard). Selanjutnya, jenis ikan lain terdiri atas cucut aron (Cacrcharinidae), cucut lutung (Alopias pelagicus), cucut monyet (Alopias superciliosus), layaran (Istiophorus platypterus), pedang-pedang (Xiphias gladius), tongkol abu-abu (Thunnus tonggol), tongkol lisong (Auxis rochel), dan lain. Jenis-jenis ikan tersebut diduga bukan hanya hasil tangkapan pancing tonda tetapi hasil tangkapan pancing ulur dan jaring hanyut yang merupakan alat tangkapan tambahan pada setiap trip operasi penangkapan ikan dengan alat tangkap pancing tonda. Di dalam pendataan di buku statistik, semua jenis ikan tersebut dimasukkan sebagai hasil tangkapan alat pancing tonda.

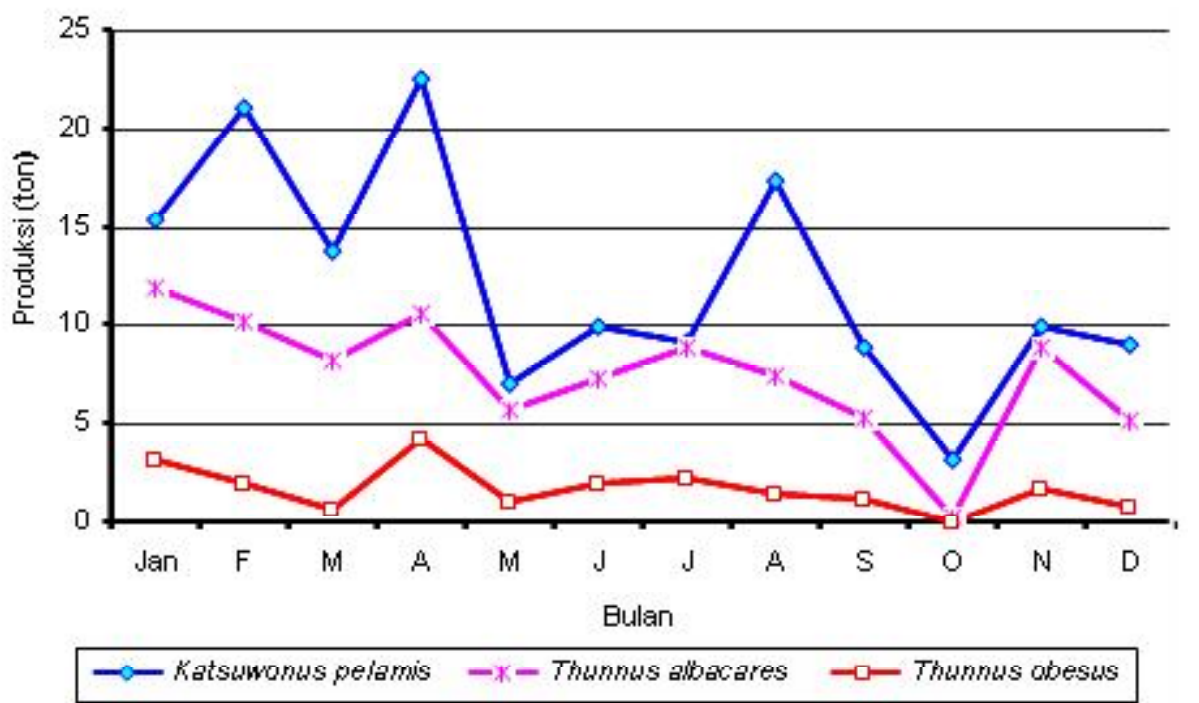

Gambar 6. Rata-rata produksi perbulan ikan sasaran penangkapan pancing tonda, tahun 2005 sampai dengan 2007. 


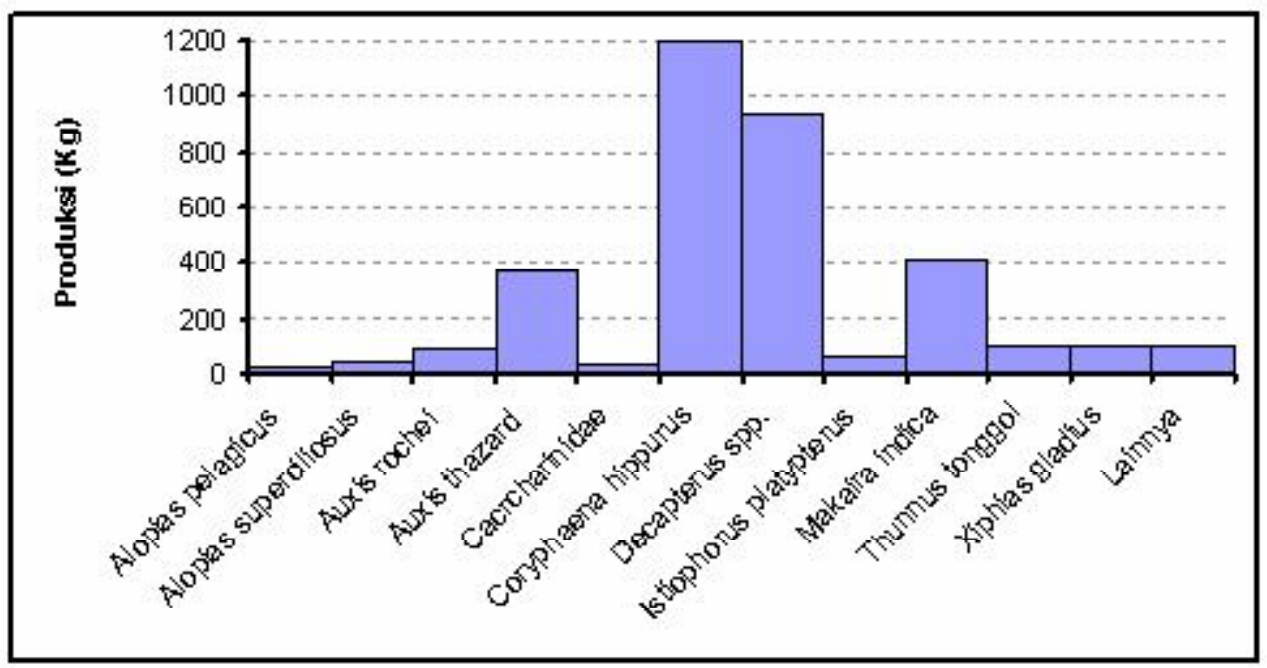

Gambar 7. Rata-rata produksi hasil tangkapan sampingan (bycatch) pancing tonda, tahun 2005 sampai dengan 2007.

\section{PENANGANAN HASIL TANGKAPAN}

Pada saat pengoperasian pancing tonda, ikan hasil tangkapan diletakkan sementara di atas kapal di bagian buritan kapal. Hal ini, dilakukan karena semua awak kapal turut serta dalam aktivitas pemancingan. Pada saat istirahat, ikan hasil tangkapan tersebut dimasukkan ke dalam palka kemudian diberi es untuk menjaga mutu ikan. Teknik penyimpanan ikan di dalam palka dilakukan dengan cara setiap lapisan ikan di dalam palka diberi es. Ikan yang disimpan paling atas, diberi es lebih banyak dibandingkan dengan ikan pada lapisan lain. Es balok yang digunakan adalah es balok yang sudah dipotongpotong (dihancurkan) menjadi bagian-bagian kecil dengan cara dipukul dengan kayu balok sehingga ukuran dan bentuk bervariasi (Rahmat, 2007).

\section{KESIMPULAN}

1. Kenaikan jumlah trip penangkapan dan jumlah kapal yang beroperasi seiring dengan meningkatkan jumlah rumpon yang dipasang.

2. Hasil tangkapan utama pancing tonda adalah ikan cakalang, tuna sirip kuning dan tuna matabesar. Sedangkan hasil tangkapan sampingan didominasi oleh lemadang, layang, jangilus, dan tongkol.

3. Hasil tangkapan rata-rata perbulan ikan target penangkapan yaitu cakalang (Katsuwonus pelamis) 12,4 ton, tuna sirip kuning (Thunnus albacares) 7,7 ton, dan tuna mata besar (Thunnus obesus) 1,8 ton.

\section{DAFTAR PUSTAKA}

Pelabuhan Perikanan Nusantara Pelabuhan Ratu. 2007. Perikanan rumpon di Pelabuhan Perikanan Nusantara Pelabuhan Ratu 2004-2007. Makalah. 10 hal. (unpublish).

Pusat Informasi Pelabuhan Perikanan. 2007. Kategori Kapal. Http://www.pipp.kp.go.id/pipp2/ alat_tangkap.html?idkat_api=6\&idapi=21. Pusat Informasi Pelabuhan Perikanan. Departemen Kelautan dan Perikanan. Bulan April 2007.

Rahmat, E. 2007. Penangkapan ikan cakalang (Katsuwonus pelamis) dan tuna (Thunnus) dengan pancing tonda di perairan Laut Banda. Kumpulan Makalah Temu Teknis dalam Rangka Apresiasi Jabatan Fungsional Teknisi Litkayasa Bidang Perikanan Tangkap. Semarang 06-08 Juni 2007. Balai Besar Pengembangan Penangkapan Ikan. Direktorat Jenderal Perikanan Tangkap. Departemen Kelautan dan Perikanan. 230 hal.

Raphita, M., Rudiarto, Rukmana, S. Mahardika, \& D. Sofyan. 2007. Data perahu motor tempel dan kapal motor yang menggunakan Pelabuhan Perikanan Nusantara Pelabuhan Ratu sebagai fishing base. Tata Operasional. Pelabuhan Perikanan Nusantara Pelabuhan Ratu. Tahun 2007. 51 hal. (unpublish).

Subani, W. \& H. R. Barus. 1989. Alat penangkapan ikan dan udang laut di Indonesia (fishing gears for marine fish and shrimp in Indonesia). Jurnal Penelitian Perikanan Laut (Edisi Khusus). No.50 Tahun 1988/1989. 248 hal. 